\title{
HENRY'S "HAND OF GOD"
}

\section{Željko Kaluđerović}

Faculty of Philosophy, Novi Sad, Department of Philosophy
Accepted: 27.03.2014.
UDC: 174

Review paper

796.332 .011 .5

\begin{abstract}
In this paper the author discusses the views and statements of the French football player Thierry Henry he gave after his illegal play during the playoff match between France and the Republic of Ireland to claim one of the final spots in the World Cup 2010 in South Africa. First, by controlling the ball with his hand before passing it on for the goal Henry has shown disregard for the constitutive rules of football. Then, by stating that he is "not a referee" he demonstrated that for some players rules are not inherent to football and that they can be relativized, given that for them winning is the goal of the highest ontological status. Furthermore, he has rejected the rules of sportsmanship, thus expressing his opinion that the opponents are just obstacles which have to be removed in order to achieve your goals. Henry's action has disrupted major moral values, such as justice, honesty, responsibility and beneficence. The rules of fair play have totally been ignored both in Henry's action and in the Football Association of France's unwillingness to comment on whether a replay should take place. They have ignored one of the basic principles stated in the "Declaration of the International Fair Play Committee", according to which, fair play is much more than playing to the rules of the game; it's about the attitude of the sportsperson. It's about respecting your opponent and preserving his or her physical and psychological integrity. Finally, the author believes that the rules, moral values and fair play in football are required for this game to become actually possible to play.
\end{abstract}

Key words: Thierry Henry, "Hand of God", The Rules of Football, Moral Values, Fair Play, Categorical Imperative

\section{HENRY'S "HAND OF GOD"}

Throughout the first part of this paper the relationship between some aspects of ethics and sport has been considered (Kaluđerović, 2011). In the second part ethics and sport ${ }^{2}$ will be viewed in connection with Albert Camus and Thierry Henry. One may ask: What is the connection between Albert Camus, a famous French writer and philosopher, and Thierry Henry, a well-known former Barcelona football player and a member of French national team; and why is it observed through a prism of ethics and sport? Maybe the following explanation will help clear things up. While writing about the educational significance of sport, Camus noted that the context in which he really learned ethics was that of sport (Camus, 1960). Camus supported the idea that sport develops values such as loyalty, courage, responsibility, altruism, team work and ability to work with others in achieving a mutual goal and excellence. In other words, this French Nobel Prize winner believed that sport offers a unique opportunity to enhance character development.

\footnotetext{
${ }^{1}$ Correspodence to:

Željko Kaluđerović, PhD, Faculty of Philosophy, Novi Sad, Department of Philosophy

Dr Zorana Đinđića 2, 21000 , Novi Sad, Serbia

Phone: +381 21459279

E-mail: zeljko.kaludjerovic@gmail.com

${ }^{2}$ For more details about ethics and sport see: McNamee, Parry, 2002.
} 
If Camus had been at the rematch between France and Ireland on 18 November 2009, he would have changed his mind. What happened during this particular match? Up to the 13th minute of extra time Ireland led 1:0, and played better than France. Then, in the 103rd minute, Henry controlled the ball illegally, with his hand, thus stopping it going out of play, and then he crossed for William Gallas to head home the goal that sent France to World Cup ${ }^{3}$. To make matters worse two French players were in an offside position during the same attack. Swedish referee Martin Hansson did not see this and he declared a goal valid. What happened next? The Irish team were understandably aggrieved, feeling that FIFA purposely stopped them from qualifying for the World Cup.Their manager Giovanni Trapattoni was so angry after the match that he did not want to comment on Henry's action, but he did say that great injustice was done his team, and that he only wanted fair play $^{4}$, which did not happen at this match ${ }^{5}$. According to the reports he allegedly said: "I go into schools to talk about fair play and then this happens"6. The Football Association of Ireland asked for a new match to be played due to the fact that a technical error by the referee has caused "irreparable damage to the integrity of sport"7.

And what was Henry's reaction? Afterwards he admitted having played with his hand. He said: "To be honest, I did use my hand, but the most important thing now is that we have qualified for the World Cup. I have played with my hand but I am not a referee. What happened? Schillaci was in action, I was behind two Irish players. The ball bounced off the ground and hit my hand. Referee did not blow the whistle. I just continued playing. What was I supposed to do? I admit it. The important thing is that we have made it to the next stage. The fact that it was this difficult only adds to the victory"8.

\footnotetext{
${ }^{3}$ According to Britannica Concise Encyclopedia football is: "Game in which two 11-member teams try to propel a ball into the opposing team's goal, using any part of the body except the hands and arms. Only the goalkeeper, when positioned within the penalty area in front of the goal, may use hands and arms". Retrieved from: http://www.answers.com/topic/soccer.

${ }^{4}$ For more details about fair play see: Sajmon, 2006.

${ }^{5}$ Retrieved from: http://sport.blic.rs/Fudbal/121396/Anri-Igraosam-rukom-video.

${ }^{7}$ Retrieved from: http://www.mondo.rs/v2/tekst. php?vest=153127.

${ }^{8}$ Irish politicians got involved in this dispute, demanding a new match.
}

French team manager Raymond Domenech said that he was pleased with the outcome and that he did not see that the captain ${ }^{9}$ of his team had played with hand. "Just like many other people at the stadium I did not see the hand. It was only in the locker room that I realized what had happened. Henry is hurt now, he does not feel well, but luckily the team support him. We should really be talking about the referee and not him"10.

How did the FIFA officials react? FIFA's Disciplinary Committee stated in its report that there is no article in the disciplinary code which could be applied in this particular situation. According to them Henry's offense could have only been sanctioned by a referee awarding an indirect free kick or a yellow card. The Disciplinary Committee reached the conclusion that there was no legal foundation for the committee to consider the case because handling the ball cannot be regarded as a serious infringement as stipulated in article $77 \mathrm{a}$ of the FIFA Disciplinary Code ${ }^{11}$. The second version, which appeared in the press, claimed that Henry's action was not a serious offense, and that according to FIFA rules if a referee fails to sanction such an action, there are no additional punishments that can be administered later on ${ }^{12}$. What message has Henry, along with the others, sent by behaving the way he did? First, he has shown disregard for the constitutive rules of football ${ }^{13}$.

${ }^{9}$ Retrieved from: http://sport.blic.rs/Fudbal/121396/Anri-Igraosam-rukom-video.

${ }^{10}$ Retrieved from: http://www.sportske.net/vest/medjunarodnifudbal/domenek-ostavite-anrija-na-miru-raspravljajteo-sudiji-10582.html. It is interesting to note that Christine Lagarde, former French minister of economy, showed greater understanding of sport rules, sport moral values and fair play than Henry and Domenech did. She said FIFA should consider replaying matches where 'cheating' was involved. The French sports teachers' union said that their national team qualified for the World cup in a deplorable manner, through cheating. It also criticized Domenech and some of the players for sending the message that: "The most important thing in sport is to win". Retrieved from: http:// www.smedia.rs/sport/print.php? $\mathrm{id}=16833$ \&vest=Sindikatnastavnika-fizickog:-Sramotan-plasman-na-SP.

${ }^{11}$ Retrieved from: http://sport.blic.rs/Fudbal//171419/FIFA-nijekaznila-Anrija-zbog-igranja-rukom.

${ }^{12}$ Retrieved from: http://www.nadlanu.com/Dynamic/News,i ntItemID, 159590, intCategoryID,471.html. FIFA officials announced that a rematch can only be played if both football associations agree to it. The rematch never happened because the French association refused the proposal.

${ }^{13}$ Constitutive rules are the rules which determine the essence of the game itself, determine the structure of a certain sport, standardize the way in which it is played and sanction unallowed sport activities. 
Then, by stating that he is "not a referee" he demonstrated that for some players rules are not inherent to football and that they can be relativized, given that for them winning is the goal of the highest ontological status. Furthermore, he has rejected the rules of sportsmanship ${ }^{14}$, thus expressing his opinion that the opponents are just obstacles which have to be removed in order to achieve your goals. The idea that an athlete should improve the opponent's performance so he could increase the level of enjoyment, for himself and the opponent probably never even entered Henry's head. Utilitarian concept of football based on capitalistic logic and business related principles has obviously prevailed over the vision in which football brings out the best in people ${ }^{15}$.

As for the moral values ${ }^{16}$, Henry's action has affected all types of justice ${ }^{17}$ mentioned earlier (Kaluđerović, 2011). He has 'annulled' distributive justice because he has turned equivalence which is based on athletes' reasonable contributions to the collective into hubristic attempt to negate all equivalence. By negating one of the vital aspects of justice, Henry has called into question the idea of justice itself. Procedural justice has been distorted because if such a drastic offense cannot be sanctioned in accordance with FIFA Code then there are regulative 'voids' within the same. The fact that Henry was not punished has also affected the retributive principle. Furthermore, since there were no attempts to do good deeds for the Irish team, on account of injustice they suffered from, compensatory justice was disrupted. It goes without saying that Henry's action and subsequent behavior are not in conformity with the moral value of honesty. Henry is, of course, familiar with the rules of the football game, but he did not want to follow them at all costs. At the match he refused to admit to the referee that he had cheated $^{18}$. Henry might have shown some 'responsibility' for his team mates and the coach, but he did not show any responsibility for the football game. This illustrates that the existing heteronomous bans are insufficient if the athletes are not aware of the general humanistic moral principles and if they do not accept responsibility for their opponents.

\footnotetext{
${ }^{14}$ Sportsmanship represents unwritten moral rules based on virtues of justice and honesty (For more details see: Keating, 1995).

${ }^{15}$ For more details see: Walsh, A., Giulianotti, 2007.

${ }^{16}$ Moral values are predominant forms of understanding of the purpose of human activity and the way in which human moral character is practically manifested. For more details about the effects of moral insensitivity in athletes see: Kretchmar, 1995.

${ }^{17}$ For more details about justice see: Kaluđerović, 2013.

${ }^{18}$ According to Gert cheating is an intentional breaking of public rules system to achieve personal gain (Gert, 1998).
}

In this day and age when the social and technological effects of science are becoming more evident (bio) ethics has to codify athlete responsibility. For this responsibility to be internalized, it should be an integral part of education from an early age. In terms of beneficence, not only has Henry disregarded its aspects of removing harm and doing well, but he has also completely ignored the idea of not doing harm and preventing harm.

The rules of fair play ${ }^{19}$ have totally been ignored both in Henry's action and in the Football Association of France's unwillingness to comment on whether a replay should take place. They have ignored one of the basic principles stated in the "Declaration of the International Fair Play Committee", according to which, fair play is much more than playing to the rules of the game; it's about the attitude of the sportsperson. It's about respecting your opponent and preserving his or her physical and psychological integrity ${ }^{20}$.

Henry's action is reminiscent of Vince Lombardi's famous remark that winning is not the most important thing; it is the only thing ${ }^{21}$. Of course every athlete hopes to win when entering the competition, but this should always be achieved within the framework set by sport rules, moral values and fair play ${ }^{22}$. Henry obviously believed that it is not cheating unless you get caught. The more cunning version of this belief is that it is referee's duty to monitor the game, and if the player is willing to face the consequences of his actions then breaking the rules is not immoral ${ }^{23}$.

${ }^{19}$ Fair play can be defined as commitment to the spirit and letter of equality of competitors in relation to the rules, and all towards the common search for excellence.

${ }^{20}$ Retrieved from: http:/www.friedenspaedagogik.de/english/ topics_of_the_institute_s_work/peace_education_online_teaching_course/basic_course_5/fair_play_definition_principles rules_and_fair_trade. Finally, if we think about the definitions of sport presented earlier (Kaluđerović, 2011), we will see that Henry has violated the aspect of sport related to the mental wellbeing as well as the one referring to the development of social interactions and relationships.

${ }^{21}$ According to S. Moriss, what Lombardi actually said was that winning is not everything, but the desire to win is (Moriss, 1979). ${ }^{22}$ For more details about sport, rules and values see: McFee, 2004.

${ }^{23}$ Defending Henry's action, his former team mate Zlatan Ibrahimović used a similar argument. In addition, he said that he would also do whatever it takes to win because: "Great players like nothing better than to win". Retrieved from: http://www. sportske.net/vest/medjunarodni-fudbal/ibrahimovic-anri-je-biou-pravu-kad-je-igrao-rukom-15616.html. Therefore, the statement of Dermot Ahern, the Irish minister of justice at the time: "If that result remains, it reinforces the view that if you cheat you will win", is well-founded. Retrieved from: http://www. theguardian.com/football/2009/nov/19/thierry-henry-handballireland-world-cup. 
Clearly, this standpoint cannot be accepted primarily because cheating gives one team or a player an unfair advantage over others. Henry's cheating is completely unacceptable, even if we 'stretch' the football rules. By looking at this particular game from the perspective of mutual quest for excellence, that both teams should have been dedicated to, we cannot but conclude that cheating, breaking the rules and unsportsmanlike conduct violate the ethical principles applied to sport events and that actions should be, or better yet, must be sanctioned ${ }^{24}$.

Some authors (Morgan, 1994) believe that commercialization has transformed sport into a product that can be bought and sold, and that the very essence of sport has been lost in the process. According to Morgan, Henry's action is a side-effect of the moral degradation in western society. If all this is true, then we need to create a moral framework which would regulate the commercial aspects of sport while upholding the inherent values of the same. The minimalist version implies that an athlete is morally responsible for achieving victory within the sport rules. The existence of the official regulatory organizations within the system is necessary so that the integrity and equality of play would be preserved, even in the ruthless world of professional football.

If we were to accept that breaking the rules is generally allowed when it is done for the greater good, for example, because we feel that France, a football superpower, deserves to be in the World Cup, then we would invalidate the very idea of sport competition. Even if winning were the athlete's only goal, he would still have to achieve it by being a better player and by adhering to the standards of the game. Abiding by the rules is the means of recognition of the equal moral status of all who, believing in the rules, comply with them. The recognition of the same moral status is important because it allows athletes to understand that the interests of others are just as important as the personal ones, which is, after all, presupposed in the very idea of fair competition. Finally, in order for the Camus' theory, that sport makes the harmony between soul and body possible to be, valid, Henry, and the other athletes should keep in mind the third formulation of the Kant's categorical imperative ac- cording to which man: "Should never treat himself or any other rational being as means to an end, but rather as always at the same time as an end" (Kant, 2004).

\section{REFERENCES}

Britannica Concise Encyclopedia. Internet address: http://www. answers.com/topic/soccer

Camus, A. (1960). The Wager of Our Generation, Resistance, Rebellion and Death, New York.

Gert, B. (1998). Morality: Its Nature and Justification. New York

Kaluđerović, Ž. (2011). Ethic and Sport, HUMAN, 1 (1),

Kaluđerović, Ž. (2013). Presokratsko razumevanje pravde. Sremski Karlovci-Novi Sad: Izdavačka knjižarnica Zorana Stojanovića

Kant, I. (2004). Zasnivanje metafizike morala. Beograd: Dereta Keating, J. W. (1995). Sportsmanship As a Moral Category, ed. W. J. Morgan and K. V. Meier, Philosophic Inquiry in Sport, Champagn Ill

Koković, D. (2010). Društvo, nasilje i sport. Novi Sad: Medit. Publish

Kretchmar, S. R. (1995). Practical Philosophy of Sport. Champaign-Urbana

McFee, G. (2004). Sport, Rules and Values. London and New York

McNamee, M. J., Parry, S. J. (2002). Ethics and Sport. London and New York.

Morgan, W. J. (1994). Leftist Theories of Sport. Urbana

Moriss, S., ed. (1979). The Book of Strange Facts and Useless Information. New York

Sajmon, R. L. (2006). FER-PLEJ. ETIKA SPORTA. Beograd: Službeni glasnik

Walsh, A., Giulianotti, R. (2007). Ethics, Money and Sport. This sporting Mammon. London and New York

Internet addresses:

http://www.mondo.rs/v2/tekst.php?vest=153127;

http://sport.blic.rs/Fudbal/121396/Anri-Igrao-sam-rukom-video; http://www.sportske.net/vest/medjunarodnifudbal/domenek-ostavite-anrija-na-miru-raspravljajteo-sudiji-10582.html; $\quad$ http://www.smedia.rs/sport/print. php?id=16833\&vest=Sindikat-nastavnika-fizickog:-Sramotanplasman-na-SP;

http://sport.blic.rs/Fudbal//171419/FIFA-nije-kaznila-Anrijazbog-igranja-rukom; http://www.nadlanu.com/Dynamic/Ne ws, intItemID, 159590, intCategoryID,471.html; http://www. friedenspaedagogik.de/english/topics_of_the_institute_s_work/ peace_education_online_teaching_course/basic_course_5/fair play_definition_principles_rules_and_fair_trade; http://www. sportske.net/vest/medjunarodni-fudbal/ibrahimovic-anri-je-biou-pravu-kad-je-igrao-rukom-15616.html;

http://www.theguardian.com/football/2009/nov/19/thierry-henry-handball-ireland-world-cup.

${ }^{24}$ For more details about society, violence and sport see: Koković, 2010 . 